\title{
32. COCCOLITH AND SILICOFLAGELLATE STRATIGRAPHY, SOUTH ATLANTIC OCEAN, DEEP SEA DRILLING PROJECT LEG 39
}

\author{
David Bukry, United States Geological Survey, La Jolla, California
}

\section{INTRODUCTION}

Leg 39 of the Deep Sea Drilling Project, September to December 1974, which began at Amsterdam, Netherlands, and ended at Cape Town, South Africa (Figure 1), recovered 165 cores at seven drilling sites, Sites 353-359. Light-microscope techniques were used to study the coccoliths and silicoflagellates of 220 samples from these sites.

As a result of studies of the silicoflagellates from Site 356, an Eocene Dictyocha spinosa Subzone is newly defined, and the definitions of the Dictyocha hexacantha Zone and Naviculopsis foliacea Zone are emended. Two new silicoflagellates are described-Mesocena venusta $\mathrm{n}$. $\mathrm{sp}$. and Macrora najae $\mathrm{n}$. sp. Several revisions of silicoflagellate taxonomy are proposed: Mesocena occidentalis Hanna ex Bukry, a validation; Mesocena tsumurai nom. nov., a substitute name; lectotype designations for Mesocena oamaruensis quadrangula Schulz and Naviculopsis biapiculata (Lemmermann); and Macrora barbadensis (Deflandre), a new combination.

\section{Site 353}

(lat $10^{\circ} 55.00^{\prime} \mathrm{N}$, long $44^{\circ} 02.25^{\prime} \mathrm{W}$, depth $5165 \mathrm{~m}$ )

Site 353 , near the north wall of the Vema Fracture Zone, was drilled primarily to sample igneous basement rock. Only three sediment cores were recovered from the interval 0 to 271 meters. The deepest sample available, 353-3-2, 138-139 cm $(262 \mathrm{~m})$, contains a warm-water late Quaternary coccolith assemblage including Ceratolithus cristatus, Gephyrocapsa oceanica, G. omega, and Helicopontosphaera wallichii.

\section{Site 354}

(lat $05^{\circ} 53.95^{\prime} \mathrm{N}$, long $44^{\circ} 11.78^{\prime} \mathrm{W}$, depth $4052 \mathrm{~m}$ )

Site 354 , on the western margin of the Ceará Rise, was drilled to determine a biostratigraphic reference section for the western equatorial Atlantic Ocean. Coccolith assemblages ranging in age from Maestrichtian to late Quaternary (Figure 2) occur in the 18 cores that were cut discontinuously between 0 and 881 meters. The Oligocene zones appear to be all present in Cores 8 to 12 (344 to $615 \mathrm{~m}$ ); zonal sequences for other series are incompletely represented.

Sample $354-4-2,130-131 \mathrm{~cm}(143 \mathrm{~m})$ contains an early Pliocene assemblage with a diverse group of ceratoliths including Amaurolithus bizzarus, $A$. delicatus, A. tricorniculatus, Ceratolithus acutus, and $C$. armatus. As in most warm-water assemblages, Scyphosphaera globulata is prominent. It is distinguished from similar $S$. globulosa by smaller aperture and by the lack of a distinctly concave base.

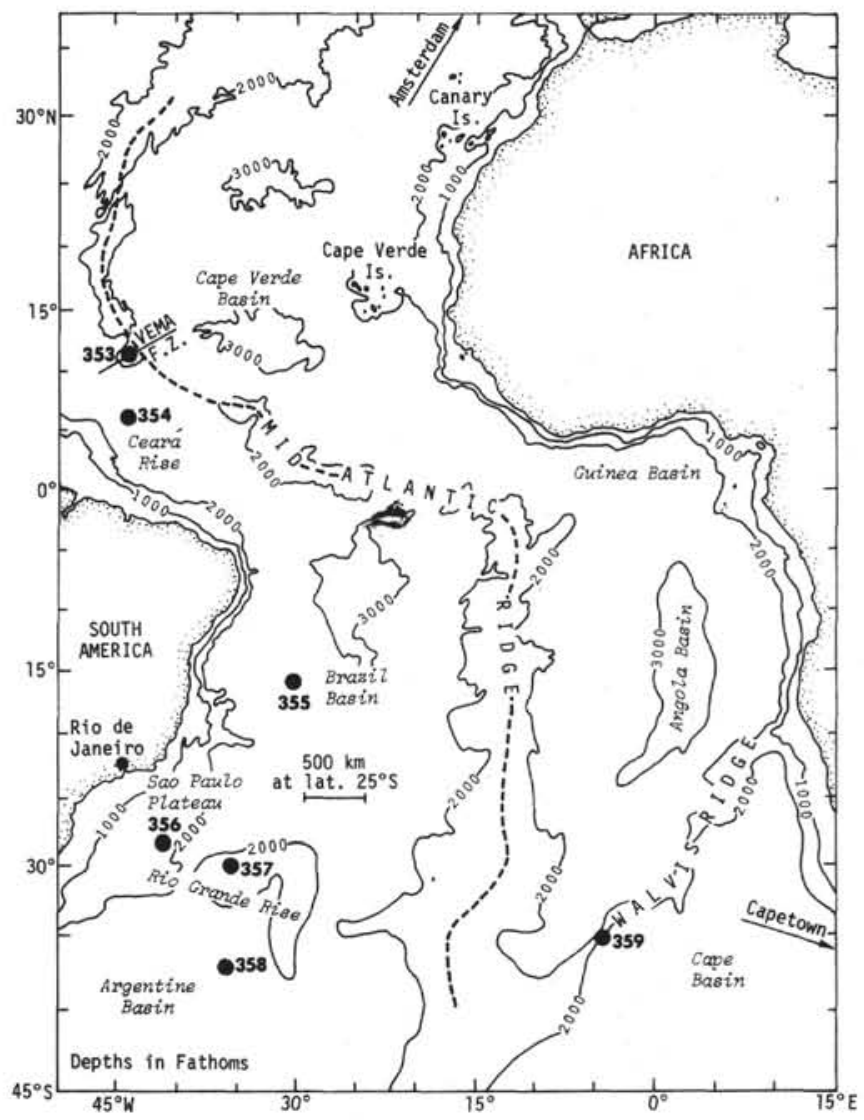

Figure 1. Sketch map of sites drilled on Deep Sea Drilling Project Leg 39.

The upper Miocene Amaurolithus primus Subzone is recognized in Samples 356-5-2, 130-131 cm $(190 \mathrm{~m})$ and $356-6-2,110-111 \mathrm{~cm}(236 \mathrm{~m})$ by the overlapping ranges of Amaurolithus amplificus, A. delicatus, A. primus, and Discoaster quinqueramus. The warm-water aspect of the coccolith assemblages is indicated by the abundant occurrence of Discoaster and Sphenolithus. The same abundance relation in the Sphenolithus heteromorphus Zone of Core 7 is augmented by the presence of Hayaster perplexus, a characteristic tropical species.

Warm-water stratigraphic-marker species of Sphenolithus and Helicopontosphaera designated by Bramlette and Wilcoxon (1967) are present through the Oligocene section of Cores 8 to 12 (344 to $615 \mathrm{~m}$ ).

Late Eocene assemblages of Core 13 (691 to $699 \mathrm{~m}$ ) contain abundant Coccolithus formosus, Cyclococcolithina? kingii, and common Reticulofenestra reticulata and discoasters. Cool-water marker species of Chiasmolithus and Isthmolithus recurvus are absent. 


\begin{tabular}{|c|c|c|c|c|c|c|c|c|c|c|}
\hline Age & Zone & Subzone & 353 & 354 & 355 & 356 & 357 & 358 & 359 & $359 A$ \\
\hline \multirow{4}{*}{ 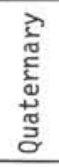 } & \multicolumn{2}{|l|}{ Emiliania huxleyi } & \multirow{2}{*}{$3-2$} & \multirow{2}{*}{$1-2$} & & & & & & \\
\hline & $\begin{array}{l}\text { Gephyrocapsa } \\
\text { oceanica }\end{array}$ & Ceratolithus oristatus & & & & & $\frac{1-2}{1-5}$ & & & \\
\hline & Crenalithus & Gephyrocapsa camibbeanica & & & & & & & & \\
\hline & doronicoides & Emitiania annula & & & & & & & & \\
\hline \multirow{5}{*}{ 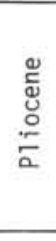 } & \multirow{3}{*}{$\begin{array}{l}\text { Discoaster } \\
\text { brouweri }\end{array}$} & $\begin{array}{l}\text { Cyclococcolithina macintyrei } \\
\text { Discoaster pentaradiatus }\end{array}$ & & & & $2-3 / 2-5$ & & & & \\
\hline & & Discoaster suroulus & & & & & & & & \\
\hline & & $\begin{array}{l}\text { Discoaster tanalis } \\
\text { Discouster asumpetricus }\end{array}$ & & $3-2$ & & $2-2$ & $\frac{2-2 / 2-4}{2-6}$ & & & \\
\hline & $\begin{array}{l}\text { Reticulofenestra } \\
\text { pseudownbilica }\end{array}$ & Sphenolithus neoabies & & & & & $2-6$ & & & \\
\hline & \multirow{2}{*}{$\begin{array}{l}\text { Amaurolithus } \\
\text { tricorniculatus }\end{array}$} & Ceratolithus mugosus & & & & & & & & \\
\hline & & $\frac{\text { Ceratolithus acutus }}{\text { Trique trorhabuzulus mosus }}$ & & $4-2 / 4-5$ & & & & & \multirow{5}{*}{$\begin{array}{c}1-1 \\
\& \\
1-4\end{array}$} & \\
\hline \multirow{10}{*}{ 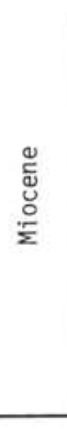 } & $\begin{array}{l}\text { Discoaster } \\
\text { quinquercrus }\end{array}$ & Amaurotithus primus & & $5-2 / 6-2$ & & & $3-4$ & & & \\
\hline & Discoaster & $\begin{array}{l}\text { Discoaster berggrent } \\
\text { Discoaster neorectus }\end{array}$ & & & & & \multirow{4}{*}{$4-2$} & & & \\
\hline & $\frac{\text { neohamatus }}{\text { Discoaster }}$ & $\begin{array}{l}\text { Discoaster bellus } \\
\text { Catinaster caluculus }\end{array}$ & & & & & & & & $1-1 / 1-4$ \\
\hline & hamatus & Helicosphaera carteri & & & & & & & & $2-2$ \\
\hline & \multicolumn{2}{|l|}{ Catinaster coalitus } & & & & & & & \multirow{2}{*}{$2-5$} & \\
\hline & Discouster exilis & $\begin{array}{l}\text { Discoaster kugleri } \\
\text { Coccolithus miopelagious }\end{array}$ & & & & & $5-2 / 5-5$ & & & \\
\hline & \multirow{2}{*}{\multicolumn{2}{|c|}{$\begin{array}{l}\text { Sphenolithus heteromorphus } \\
\text { Helicosphaera ampliaperta } \\
\text { Sphenotithus belemnos }\end{array}$}} & & $7-2 / 7-4$ & $2-4$ & & $6-1 / 6-4$ & & & \\
\hline & & & & & & $3-1 \& 1 \mathrm{~A}-2$ & $7-3$ & & & \\
\hline & \multirow{2}{*}{$\begin{array}{l}\text { Triquetrophabdulus } \\
\text { carinatus }\end{array}$} & Discoaster dmugii & & $8-1$ & & $3-3 / 4-5$ & & & & \\
\hline & & $\begin{array}{l}\text { Discoaster deflandrei } \\
\text { Cyclicargolithus abisectus }\end{array}$ & & $? 8-3 / 9-2$ & & $\frac{5-1 / 5-3}{5-6}$ & $\frac{-3-3}{9-3 / 13-3}$ & & & \\
\hline \multirow{5}{*}{ 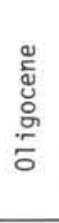 } & Sphenolithus & Dictyococcites bisectus & & $9-5 / 10-5$ & & $1 A-5 / 2 A-6$ & $15-2 / 18-2$ & & & \\
\hline & \multirow{2}{*}{\multicolumn{2}{|c|}{$\begin{array}{l}\text { Sphenolithus distentus } \\
\text { Sphenolithus predistentus } \\
\end{array}$}} & & $\frac{? 11-2}{11-5 / 11-6}$ & & & & & & \\
\hline & & & & $\frac{11-5 / 11-6}{?: 12-1}$ & & & $79-2$ & & & \\
\hline & \multirow{2}{*}{$\begin{array}{l}\text { Helicosphaera } \\
\text { reticulata }\end{array}$} & $\begin{array}{l}\text { Reticulofenestra hillace } \\
\text { coccolithus formosus }\end{array}$ & & $12-3 / 12-6$ & & & & & & \\
\hline & & $\begin{array}{l}\text { Coccolithus formosus } \\
\text { cocolithus subdistichus }\end{array}$ & & & & & & & & \\
\hline \multirow{10}{*}{ 芯 } & \multirow{3}{*}{$\begin{array}{l}\text { Discoaster } \\
\text { barbadiensis } \\
\text { Reticulofenestra } \\
\text { umbilica } \\
\end{array}$} & $\begin{array}{l}\text { Isthmolithus recurvus } \\
\text { Chiasmolithus ormamuensis }\end{array}$ & & \multirow[t]{2}{*}{$13-2 / 13-5$} & & & $20-2 / 20-3$ & & $\frac{2-684-1}{3-2 / 3-4}$ & \\
\hline & & $\begin{array}{l}\text { Chiasmolithus ormaruensis } \\
\text { Discaster saipconensis } \\
\end{array}$ & & & & & $21-1 \mid 22-21$ & & $3-2 / 3-4$ & \\
\hline & & Discoaster bifax & & & & $\frac{6-2 / 6-6}{7-2 / 7}$ & $24-2 / 24-5 \mid 23-5$ & & & \\
\hline & \multirow{2}{*}{$\begin{array}{l}\text { Nannotetrina } \\
\text { quadrata }\end{array}$} & $\begin{array}{l}\text { Coceolithus staurion } \\
\text { Chiasmotithus gigas }\end{array}$ & & $14-2$ & & $\frac{7-2 / 7-5}{8-2 / 9-2}$ & $\frac{25-3}{26-2}$ & & & \\
\hline & & \begin{tabular}{|l|} 
Chrasmolrthus gigas \\
Discoaster strictus \\
\end{tabular} & & $14-5$ & & $10-2$ & $26-5 / 28-2$ & & & \\
\hline & Discoaster. & Rhabdosphaera inflata & & & & $10-3 / 10-4$ & $28-5$ & & & \\
\hline & sublodoensis & Discoasteroides kuepperi & & & & & & & & \\
\hline & Discoaster Zodoensis & & & & & $\frac{11-1 / 14-1}{15-216-2}$ & & $\frac{11-4 / 12-3}{12,2 / 12 / 4}$ & & \\
\hline & $\begin{array}{l}\text { Tribrachiatus orthos } \\
\text { Discoaster }\end{array}$ & us & & & & $15-2 / 16-2$ & & $\frac{12-3 / 12-4}{12-4 / 12-6}$ & & \\
\hline & $\begin{array}{l}\text { Discoaster } \\
\text { diastypus }\end{array}$ & Tribrachiatus contortus & & & & & & & & \\
\hline & $\begin{array}{l}\text { Discoaster } \\
\text { multinadiats }\end{array}$ & $\begin{array}{l}\text { Campylosphaera eodela } \\
\text { Chismotithus bidens }\end{array}$ & & $\frac{15-2}{16-3 / 16-5}$ & & & & & & \\
\hline Еัँ & \begin{tabular}{|l|} 
multiradiatus \\
Discoaster nobilis \\
\end{tabular} & Chiasmolithus bidens & & $10-3 / 10-2$ & & & & & & \\
\hline$\stackrel{\square}{\circ}$ & $\begin{array}{l}\text { Discoaster mohlem } \\
\text { Heliolithus kleinpel }\end{array}$ & & & $16-6$ & & $17-1 / 17-5$ & & & & \\
\hline$\pi$ & Fasciculithus tympan & prmis & & & & $18-2 / 18-5$ & $29-1$ & $13-1$ & & \\
\hline & Cruciplacolithus ter & & & & & $19-2 / 29-2$ & $30-1 / 30-5$ & $13-4 / 14-3$ & & \\
\hline
\end{tabular}

Figure 2. Cenozoic coccolith zonation of core samples from Deep Sea Drilling Project Leg 39 sites. The numbers assigned to zonal intervals are core and section numbers of samples examined. Where a zone or subzone is represented in more than one sample, the highest and lowest are given. Poorly diagnostic samples má bracket several zonal intervals. 
Relatively shallow deposition is suggested by the presence of the solution-prone species Helicopontosphaera reticulata and Pedinocyclus larvalis.

The middle Eocene of Core 14 (701 to $739 \mathrm{~m})$, like the upper Eocene, is characterized by diverse but poorly preserved assemblages. Among the few Chiasmolithus present, C. gigas in 354-14-2, $128-129 \mathrm{~cm}$ $(703 \mathrm{~m})$ is a stratigraphic guide to the middle middle Eocene $C$. gigas Subzone of low latitudes.

The overlap of Campylosphaera eodela, Discoaster multiradiatus, and Toweius eminens in Sample 354-15-2, $61-62 \mathrm{~cm}(815 \mathrm{~m})$ indicates the uppermost Paleocene Campylosphaera eodela Subzone. The diverse assemblages from Core 16, Sections 3 to 5, lack $C$. eodela and are assigned to the next older Chiasmolithus bidens Subzone of the Discoaster multiradiatus Zone. An overlap of Discoasteroides megastypus, Heliolithus kleinpellii, and $H$. riedelii without associated discoasters in Sample 354-16-6, 130-131 cm (841 m) indicates the upper Paleocene $H$. kleinpellii Zone. Therefore, the intervening Discoaster mohleri Zone and D. nobilis Zone of the upper Paleocene are missing or very compressed.

Maestrichtian assemblages in Cores 17 and 18 ( 853 to $881 \mathrm{~m})$ are diverse but many specimens are fragmented as in the Paleogene. No short-ranged marker species were observed (Figure 3).

\section{Site 355}

(lat $15^{\circ} 42.59^{\prime} \mathrm{S}$, long $30^{\circ} 36.03^{\prime} \mathrm{W}$, depth $4896 \mathrm{~m}$ )

Site 355, in the Brazil Basin was intended to date the basement to help calibrate the paleomagnetic reversal time scale for the late Cretaceous.
The only definitive coccolith assemblage in four samples examined from Cores 1 to 3 (53 to $117 \mathrm{~m}$ ) is in Sample 355-2-4, 130-31 cm (117 m) and belongs to the Sphenolithus heteromorphus Zone. The warm-water assemblage includes: Coccolithus pelagicus, Cyclicargolithus floridanus, Cyclococcolithina macintyrei, Discoaster deflandrei, D. exilis, D. moorei, D. signus, D. variabilis, Hayaster perplexus, Helicopontosphaera kamptneri, and Sphenolithus heteromorphus.

The deepest samples available from Cores 17 to 20 ( 405 to $443 \mathrm{~m}$ ) are dissolution concentrates of coccolith fragments along with resistant species such as Broinsonia parca, Cylindralithus gallicus, Micula decussata, and Watznaueria barnesae. The two lowest samples lack the guide fossils Tetralithus trifidus and Eiffellithus eximius and are assigned to the middle to upper Campanian Broinsonia parca Zone.

\section{Site 356}

(lat $28^{\circ} 17.22^{\prime} \mathrm{S}$, long $41^{\circ} 05.28^{\prime} \mathrm{W}$, depth $3203 \mathrm{~m}$ )

Site 356, near the southeastern margin of the São Paulo Plateau, was designed to determine the duration and nature of South Atlantic evaporite deposits and the nature of basement rocks underlying the evaporites. Coccoliths of Late Cretaceous to Quaternary age are abundant through the 44 cores cut between 0 and 741 meters subbottom. As a result of hiatuses, zonal sequences are only present for the lower Miocene, Eocene, Paleocene, and Upper Cretaceous.

Eocene assemblages are especially diverse and contain several moderately solution-prone taxa such as Scyphosphaera, but lack pentalith taxa typical of shallow-water deposits. For example, Sample 356-6-5,

\begin{tabular}{|c|c|c|c|c|c|c|}
\hline \multirow[b]{2}{*}{ Age } & \multirow[b]{2}{*}{ Zone } & \multicolumn{5}{|c|}{ Site } \\
\hline & & 354 & 355 & 356 & 357 & 358 \\
\hline \multirow{3}{*}{ Maestrichtian } & Micula mura & \multirow{2}{*}{$17-1 / 18-5$} & & $29-3$ & $31-1 / 31-3$ & \multirow{2}{*}{$16-2$} \\
\hline & $\begin{array}{l}\text { Lithraphidites } \\
\text { quadratus }\end{array}$ & & & $30-3 / 31-3$ & $? 32-2$ & \\
\hline & Tetralithus trifidus & & $17-2 / 18-2$ & $33-3 / 33-6$ & $34-2 / 36-2$ & \\
\hline \multirow[t]{2}{*}{ Campanian } & Broinsonia parca & & $? 19-2 / 20-2$ & $34-3 / 34-6$ & & \\
\hline & Eiffelzithus eximius & & & & $40-2 / 43-2$ & \\
\hline Santonian & Gartnerago obliquum & & & & & \\
\hline \multirow{2}{*}{ Coniacian } & $\begin{array}{l}\text { Marthasterites } \\
\text { furcatus }\end{array}$ & & & $35-3 / 40-3$ & $44-2 / 49-2$ & \\
\hline & $\begin{array}{l}\text { Micula decussatal } \\
\text { Tetralithus pyramidus }\end{array}$ & & & & $51-2$ & \\
\hline \multicolumn{2}{|c|}{ Cenomanian to Coniacian } & & & $41-2 / 44-3$ & & \\
\hline
\end{tabular}

Figure 3. Mesozoic coccolith zonation of core samples from Deep Sea Drilling Project Leg 39. 
$130-131 \mathrm{~cm}(121 \mathrm{~m})$, of the middle Eocene Discoaster bifax Subzone includes: Campylosphaera dela, Chiasmolithus grandis, C. solitus, Coccolithus formosus, Discoaster barbadiensis, D. bifax, D. distinctus, $D$. nodifer, Helicopontosphaera compacta, Lophodolithus acutus, Nannotetrina quadrata, Reticulofenestra sp. cf. $R$. hillae, $R$. samodurovii, Rhabdosphaera tenuis, Scyphosphaera expansa, Sphenolithus radians, $S$. furcatolithoides, Syracosphaera formosa, and Zygolithus dubius.

Silicoflagellates occur sparsely through the middle Eocene in Cores 6 to 9 (114 to $200 \mathrm{~m})$. Stratigraphic marker species Dictyocha spinosa and Naviculopsis foliacea occur in all four cores, whereas Dictyocha hexacantha s. str. occurs only in the upper two (Table l). This distribution indicates that the Dictyocha hexacantha Zone of late middle and late Eocene age (Bukry and Foster, 1974) is only as old as the late Nannotetrina quadrata Zone of coccoliths at Site 356 (Figure 2), according to the first occurrence of $D$. hexacantha sensu stricto. The older occurrence of $D$. spinosa, recorded as early as the Chiasmolithus gigas Subzone (coccolith) at Sites 208 and 356, suggests an additional cosmopolitan biostratigraphic unit, the Dictyocha spinosa Subzone within the Naviculopsis foliacea Zone below and $D$. hexacantha Zone above (see Silicoflagellate Zonation).

Siliceous phytoplankton are missing in Core 10 (219 to $228 \mathrm{~m}$ ), where the lower middle Eocene Rhabdosphaera inflata Subzone of coccoliths is easily determined by the presence of diverse assemblages, including, in 356-10-3, 130-131 cm (222 m): Campylosphaera dela, Chiasmolithus grandis, C. solitus, Coccolithus formosus, Cyclicargolithus pseudogammation, Discoaster barbadiensis, D. sp. cf. D. gemmifer, D. mirus, D. sublodoensis, Ellipsolithus lajollaensis, Helicopontosphaera lophota, $H$. seminulum, Lophodolithus nascens, $L$. rotundus, Reticulofenestra dictyoda, $R$. samodurovii, Rhabdosphaera inflata, Syracosphaera fimbriata, Zygolithus dubius, Zygrhablithus bijugatus.

Paleocene coccolith assemblages are diverse and contain many species of Fasciculithus. The Danian Cruciplacolithus tenuis Zone contains Fasciculithus sp. cf. $F$. involutus, $F$. janii, and $F$. pileatus, below the range of $F$. tympaniformis, in the Cyclococcolithina? robusta Subzone of Gartner (1971), for example in Samples $356-19-2,130-131 \mathrm{~cm}(316 \mathrm{~m})$ and $356-21-3,130-131 \mathrm{~cm}$ $(336 \mathrm{~m})$. A mixed-assemblage interval in upper Core 29 and lower Core 28 has a high proportion of Cretaceous taxa in the early Danian assemblage, which is identified by Cruciplacolithus tenuis or Coccolithus pelagicus s. ampl. in samples as deep as Sample 356-29-2, 129-131 $\mathrm{cm}(411 \mathrm{~m})$. The Maestrichtian guide fossil Lithraphidites quadratus, which is generally missing in Pacific and Indian ocean cores, occurs at Site 356 in Cores 29 to 31. A persistent occurrence of Marthasterites furcatus in Cores 35 to 40 , especially common in Core 40 , is a guide to the Coniacian and Santonian stages of the Late Cretaceous.

Older assemblages of Cores 41 to 44 are less diagnostic. In Sample 356-42-3, 140-141 cm (717 m), Tetralithus sp. cf. T. pyramidus suggests a Turonian or younger age. Nannoconus sp. cf. $N$. globulus and $N$. sp. cf. N. kamptneri are present. On the basis of a general similarity in assemblage, including Braarudosphaera bigelowii, Eiffellithus turriseiffeli, and Nannoconus sp. cf. N. globulus, 356-44-3, 147-148 cm (735 m), is probably post-Albian; however, it could be as old as late Albian, by the earliest occurrence of $E$. turriseiffeli (Thierstein, 1971).

TABLE 1

Middle Eocene Silicoflagellates at DSDP 356 Recorded as Percents. Samples Above 134 Meters are Assigned to the Dictyocha hexacantha Zone, From 137 to 190 Meters to the Dictyocha spinosa Subzone, and From 192 Meters, Tentatively, to an Unnamed Lower Subzone of the Naviculopsis foliacea Zone

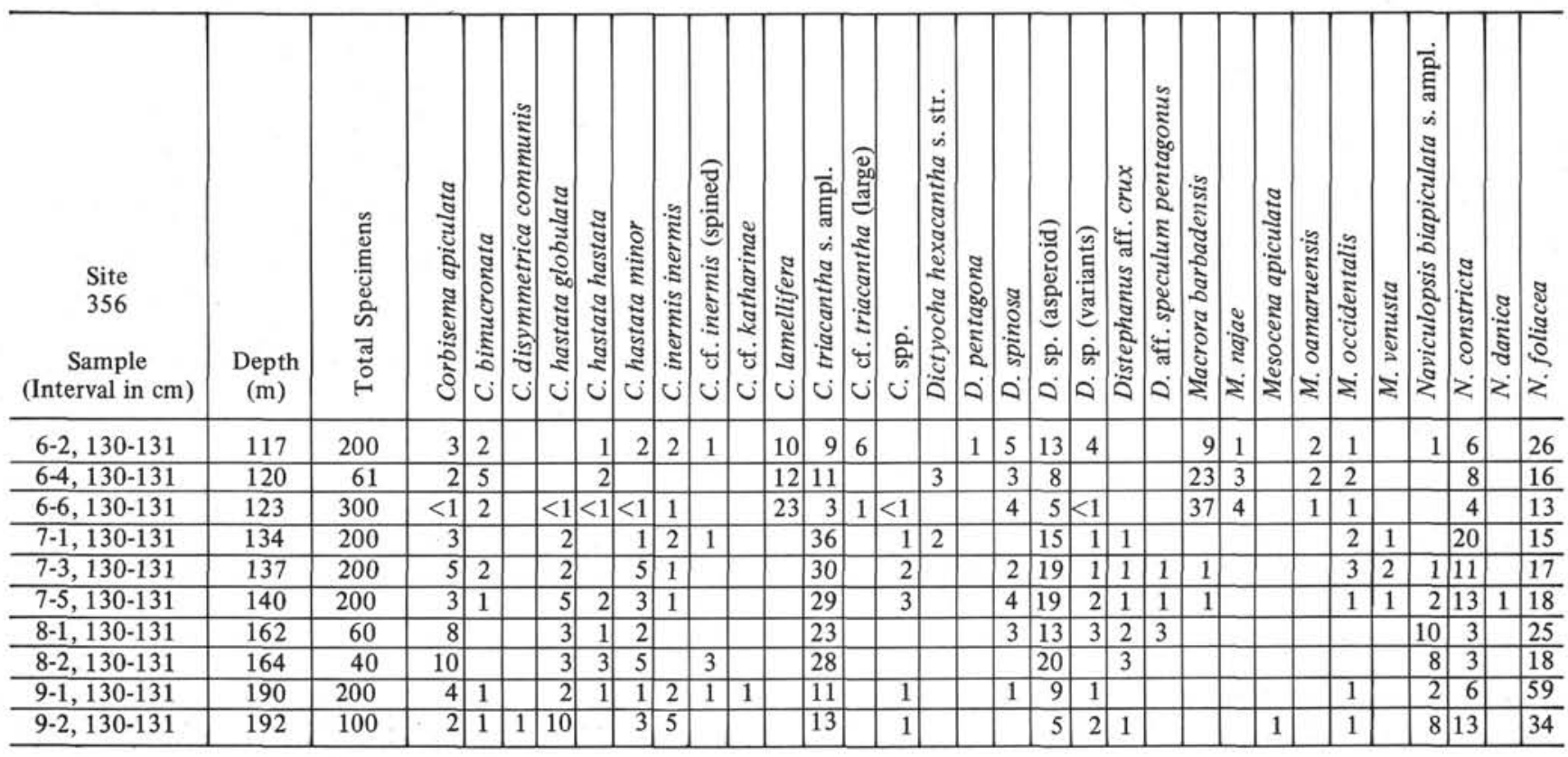




\section{Site 357}

(lat $30^{\circ} 00.25^{\prime} \mathrm{S}$, long $35^{\circ} 33.59^{\prime} \mathrm{W}$, depth $2109 \mathrm{~m}$ )

Site 357 , on the northern flank of the Rio Grande Rise, was drilled to complete the stratigraphic record to basement, originally attempted during Leg 3 at Sites 21 and 22 .

Generally diverse coccolith assemblages range in age from Turonian or Coniacian to late Quaternary. Discoasters have moderate to heavy overgrowths in most of the Tertiary assemblages.

Rare reworked specimens of Discoaster brouweri and D. variabilis belie the true age of Sample 357-1-5, 130$131 \mathrm{~cm}(7 \mathrm{~m})$. An overlap of Emiliania ovata and Gephyrocapsa oceanica indicates the upper Quaternary Emiliania ovata Subzone.

Like Site 356, the middle Eocene assemblages are diverse and contain shallow oceanic taxa such as Scyphosphaera. Even shallower Eocene marine conditions are indicated at Site 357 , however, by the presence of Braarudosphaera, Micrantholithus, and Pemma. The cool-water marker species, Chiasmolithus oamaruensis and Isthmolithus recurvus, are rare in upper Eocene Core 20 (256 to $265 \mathrm{~m})$, where the great abundance of Discoaster suggests mainly warm-water conditions.

The lowest sample from Core 28, Sample 357-28$5,110-111 \mathrm{~cm}(443 \mathrm{~m})$, contains Discoaster sublodoensis, Reticulofenestra dictyoda, and Rhabdosphaera inflata, a diagnostic association for the Rhabdosphaera inflata Subzone at the base of the middle Eocene. Owing to a coring gap, the next deeper Sample 357-29-1, 129-130 $\mathrm{cm}(466 \mathrm{~m})$, contains the much older Fasciculithus tympaniformis Zone of the Paleocene. Fasciculithus magnus is common in Sample 357-30-1, 130-131 cm $(475 \mathrm{~m})$, which is below the range of $F$. tympaniformis in the Cruciplacolithus tenuis Zone. Cretaceous assemblages in Cores 31 to $51(493$ to $797 \mathrm{~m})$ resemble those at Site 356, but no Lithraphidites quadratus were found at this site.

\section{Site 358}

(lat $37^{\circ} 39.31^{\prime} \mathrm{S}$, long $35^{\circ} \mathbf{5 7 . 8 2} \mathrm{W}$, depth $5000 \mathrm{~m}$ )

Site 358, in the Argentine Basin, was intended to date the basement to help calibrate the paleomagnetic reversal time scale for the Late Cretaceous.

The siliceous mudstones in Cores 1 to 11 (48 to 713 $\mathrm{m})$ contain sparse silicoflagellates at some levels, but coccoliths are missing. The last coccoliths preserved at Site 358 are of early Eocene age, in the lower part of Core 11. Silicoflagellates in samples from the mudstone section are too sparse to make valid stratigraphic counts. The occurrence of specimens or fragments of Dictyocha sp. cf. D. pulchella, Distephanus crux, D. speculum, Mesocena circulus, and $M$. diodon indicates a tentative upper Miocene assignment for Sample 358-2$2,130-131 \mathrm{~cm}(126 \mathrm{~m})$. A lower Miocene assignment is suggested by rare specimens of Distephanus crux and Naviculopsis sp. cf. N. quadrata in Sample 358-4-2, 140$141 \mathrm{~cm}(278 \mathrm{~m})$. Similarly, the rare D. crux, Mesocena apiculata, $N$. biapiculata, and the diatom Stictodiscus gelidus (syn. Rocella gemma) in Sample 358-5-1, 145$146 \mathrm{~cm}(352 \mathrm{~m})$, suggest a late Oligocene or early Miocene age. The only silicoflagellates found in Sample
358-6-3, 140-141 cm $(421 \mathrm{~m})$ are fragments of Naviculopsis sp.; however, the abundant occurrence of Stictodiscus gelidus represents part of the latest Oligocene or earliest Miocene acme of that species as indicated by the stratigraphic results of DSDP Legs 28 , 29 , and 36, and by Ling (1972).

The overlapping ranges of Coccolithus crassus, $C$. magnicrassus, and Discoaster lodoensis, without D. sublodoensis, in Samples 357-11-4, 11-12 $\mathrm{cm}(708 \mathrm{~m})$ to $357-12-3,55-56 \mathrm{~cm}$ (754 m) determine the lower Eocene Discoaster lodoensis Zone (Bukry, 1973a). Coccolithus magnicrassus is abundant in the Tribrachiatus orthostylus Zone of Samples 358-12-3, 104-105 cm (754 m) and $358-12-4,47-48 \mathrm{~cm}(756 \mathrm{~m})$. The Discoaster binodosus Subzone of the Discoaster diastypus Zone is indicated in Samples 358-12-4, 89-90 cm (758 m) to 358$12-6,82-83 \mathrm{~cm}(758 \mathrm{~m})$, the the occurrences of Discoaster binodosus, D. diastypus, Discoasteroides kuepperi, and Tribrachiatus orthostylus, in the absence of Discoaster lodoensis.

Several nonfossiliferous samples of ferruginous mudstone in Cores 15 and 16 intervene between early Paleocene coccoliths in Cores 13 and 14 (779 to $798 \mathrm{~m}$ ) and a Maestrichtian assemblage in Sample 358-16-2, $128-129 \mathrm{~cm}(819 \mathrm{~m})$, which is a dissolution concentrate dominated by Micula decussata.

\section{Site 359}

lat $34^{\circ} 59.10^{\prime} \mathrm{S}$, long $04^{\circ} 29.83^{\prime} \mathrm{W}$, depth $1658 \mathrm{~m}$ )

Site 359 , on a seamount of the Walvis Ridge, was an unscheduled site of serendipity near the end of Leg 39. Six sediment cores were cut before Glomar Challenger had to diesel for port at Cape Town.

Samples from middle or late Miocene assemblages are poorly diagnostic, and the discoasters are thickly overgrown. An overlap of Discoaster sp. cf. D. neohamatus and $D$. sp. cf. D. pentaradiatus in Core 1A and the occurrence of Catinaster calyculus in Core 2A provide some restricted guides to correlation (Figure 2).

Shallow-water late Eocene assemblages of Cores 2 to $4(37$ to $95 \mathrm{~m})$ contain a wealth of coccolith guide fossils similar to Caribbean and European localities, including Braarudosphaera rosa, Chiasmolithus oamaruensis, Corannulus germanicus, Discolithina latoculata, Isthmolithus recurvus, Micrantholithus ornatus, Orthozygus aureus, and Peritrachelina joidesa. The presence of Scyphosphaera and the common occurrence of pentaliths indicate shallower deposition than at the western South Atlantic Sites 354 and 357 for the upper Eocene.

\section{SILICOFLAGELLATE ZONATION}

The Eocene silicoflagellates at Site 356 of Leg 39 suggest several modifications in zonation and taxonomy for the Paleogene. The boundary criteria for the Dictyocha hexacantha Zone and Naviculopsis foliacea Zone are altered and a new Dictyocha spinosa Subzone is proposed.

\section{Corbisema hastata Zone}

Following the discovery of assemblages of the Corbisema hastata Zone and Naviculopsis constricta Zone associated with upper Paleocene coccoliths at Site 327 of Leg 36, the top of the zone was lowered below 
the original tentative position at the Paleocene-Eocene boundary (Figure 4).

\section{Naviculopsis constricta Zone}

Glezer (1966) and Martini (1974) suggested the occurrence of specimens similar to Naviculopsis foliacea in the lower Eocene. This species is believed to be an important stratigraphic marker because of: (l) its consistent abundance in the middle Eocene at Site 356, (2) distinctive morphology, (3) cosmopolitan distribution, and (4) evolutionary development after the establishment of populations of $N$. constricta in the late Paleocene. Therefore, the top of the $N$. constricta Zone is tentatively lowered below the lower to middle Eocene boundary to the first occurrence of $N$. foliacea.

\section{Naviculopsis foliacea Zone}

The Naviculopsis foliacea Zone was originally indicated by Martini (1974) as the interval between the first Dictyocha bimucronata and the last Dictyocha spinosa. The top of the zone probably needs modification because of the Oligocene range of
Dictyocha spinosa suggested by Perch-Nielsen (1975). The first occurrence of Dictyocha hexacantha is selected as the new marker for the top of the zone; this will limit the range of the zone to the Eocene in most regions. The first occurrence of the name-giving species Naviculopsis foliacea is designated as the base of the zone because it is large distinctive, and widespread.

The difference in range between Dictyocha hexacantha and D. spinosa, mentioned in Bukry (1975), occurs at Site 356 and indicates that the upper part of the Naviculopsis foliacea Zone, below the Dictyocha hexacantha Zone, can be designated the new Dictyocha spinosa Subzone, on the basis of the earlier first occurrence of $D$. spinosa.

\section{Dictyocha hexacantha Zone}

Originally, the base of this zone was determined by the first occurrence of Dictyocha hexacantha s. ampl. which included Dictyocha spinosa; however, the definition is herein restricted to the first occurrence of $D$. hexacantha s. str. Because of the later appearance of $D$. hexacantha s. str., the duration of the zone is shortened.

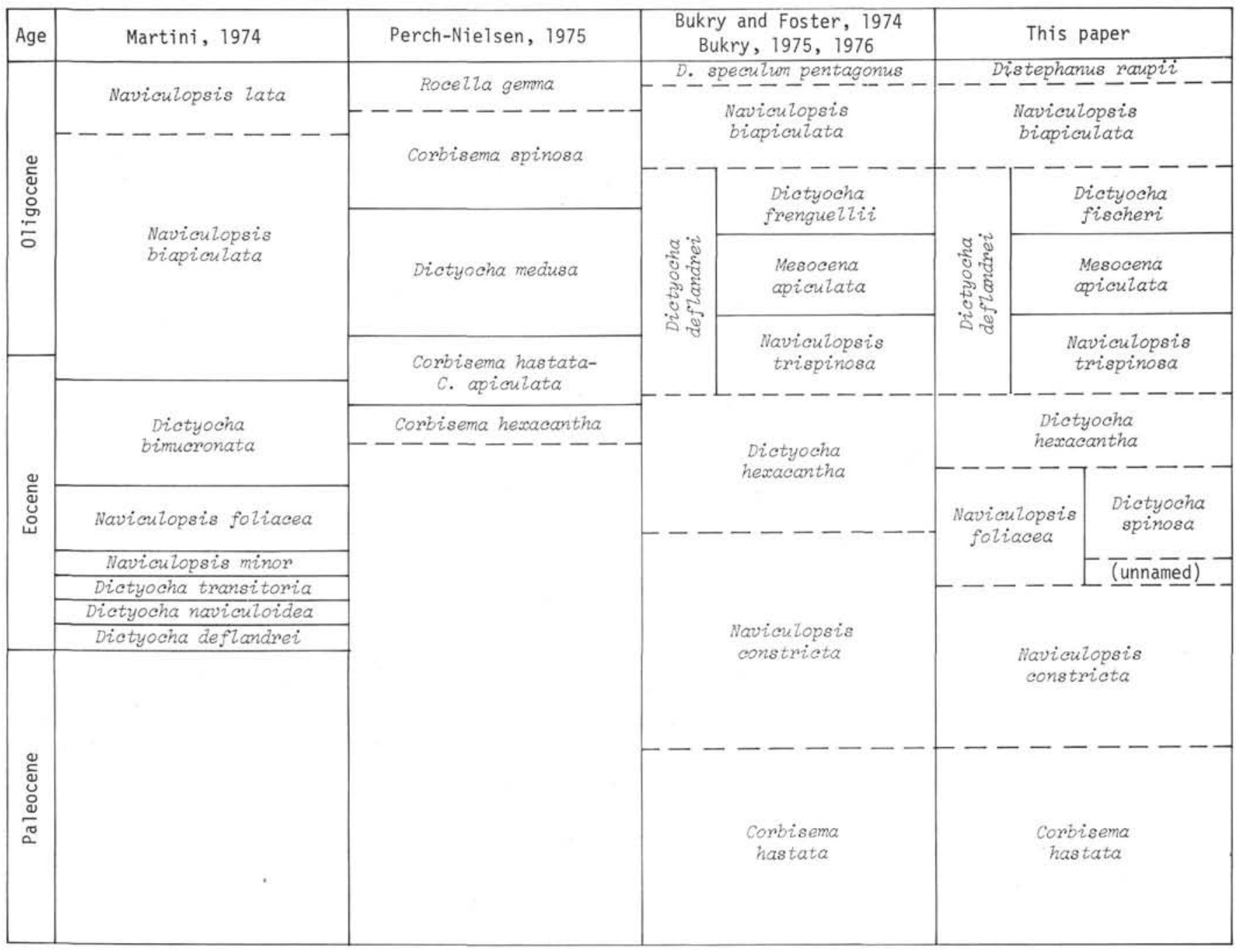

Figure 4. Comparison of some proposed zonal sequences of Paleogene silicoflagellates. 


\section{Other Paleogene Zones}

The remaining zones of the Paleogene are unchanged, except for taxomonic changes, from their descriptions for Leg 29 (Bukry, 1975).

\section{SILICOFLAGELLATE TAXONOMY}

Genus CORBISEMA Hanna, 1928

Corbisema apiculata (Lemmermann)

Dictyocha triacantha apiculata Lemmermann, 1901, Deutsche Bot. Ges. Ber., v. 19, p. 259 , pl. 10, fig. 19, 20

Corbisema apiculata (Lemmermann), Perch-Nielsen, 1975, Deep Sea Drilling Proj. Initial Repts., v. 29, p. 685, pl. 2, fig. 5, 16, 19; pl. 3 , fig. $19,20,14$; pl. 15 , fig. 1,2 .

\section{Corbisema bimucronata Deflandre}

(Plate 1, Figure 1)

Corbisema bimucronata Deflandre, 1950, Microscopie, v. 2, p. 191, fig. 174-177

Corbisema disymmetrica communis Bukry

Corbisema disymmetrica communis Bukry, 1976, Deep Sea Drilling Proj. Initial Repts., v. 35, p. 891 , pl. 1, fig. 5-9.

\section{Corbisema hastata globulata Bukry} (Plate 1, Figure 2)

Corbisema hastata globulata Bukry, 1976, Deep Sea Drilling Proj. Initial Repts., v. 35 , p. 892 , pl. 4 , fig. 1-8.

\section{Corbisema hastata hastata (Lemmermann)}

Dictyocha triacantha hastata Lemmermann, 1901, Deutsche Bot. Ges., Ber., v. 19, p. 259 , pl. 10, fig. 16,17 .

\section{Corbisema hastata minor (Schulz)}

Dictyocha triacantha apiculata minor Schulz, 1928 (in part), Bot. Archiv, v. 21 , p. 249 , fig. 29 b.

\section{Corbisema inermis inermis (Lemmermann)} (Plate I, Figure 3)

Dictyocha triacantha inermis Lemmermann, 1901, Deutsche Bot. Ges., Ber., v. 19, p. 259, pl. 10, fig. 21.

Remarks: Compared specimens of Corbisema inermis inermis have small spines. Typical specimens of this species lack spines (Bukry, 1976)

\section{Corbisema sp. cf. C. katharinae Bukry}

Corbisema katharinae Bukry, in press, Deep Sea Drilling Proj. Initial Repts., v. 38 , p. 848 , pl. 1, fig. 1-6.

Remarks: The single specimen from Site 356 is smaller and has a less developed plate than typical specimens from Leg 38 .

\section{Corbisema lamellifera (Glezer)}

(Plate I, Figrues 4, 5)

Dictyocha lamellifera Glezer, 1962, Paleont. Zhur. 1962, no. I, p. 150 , fig. $3 b, v$.

Dictyocha lamellifera constricta Glezer, 1964, Akad. Nauk SSSR, Novosti sistematiki nizshikh rasteniy, otdel. ottisk, p. 50 , pl. I, fig. 3 .

Dictyocha lamellifera lamellifera Glezer, 1964, p. 48, pl. 1, fig. 2.

Remarks: Spine lengths of specimens from Site 356 are intermediate between the end members of Glezer's (1964) type suite. The Atlantic specimens have wider apical struts.

\section{Corbisema triacantha (Ehrenberg) s. ampl.}

Dictyocha triacantha Ehrenberg, 1844, K. Preuss. Akad. Wiss. Berlin, Ber., Jahrg. 1844 , p. 80 .

Remarks: The small form Corbisema triacantha minor (see Ling, 1972) was not separated from moderate sized forms of this equilateral species (see Bukry and Foster, 1974). Some especially large, pinched specimens in Core 6 at Site 356 are tabulated as compared species.

\section{Corbisema spp.}

Remarks: Broken, tilted, or unnamed variants or species are grouped together under this heading.

\section{Genus DICTYOCHA Ehrenberg, 1837}

\section{Dictyocha hexacantha Schulz}

Dictyocha hexacantha Schulz, 1928, Bot. Archiv, v. 21, no. 2, p. 255, fig. 43.

Corbisema hexacantha (Schulz), Perch Nielsen, 1975, Deep Sea Drilling Proj. Initial Repts., v. 29, p. 685, pl. 3, fig. 13, 14.

\section{Dictyocha pentagona (Schulz}

Dictyocha fibula var. pentagona Schulz, 1928, Bot. Archiv, v. 21 , no. 2 , p. 255 , fig. $41 \mathrm{a}$, b.

Remarks: Two large specimens of this long-ranged form taxon (Bukry, 1976) were found at Site 356.

\section{Dictyocha sp. cf. D. pulchella Bukry}

Dictyocha pulchella Bukry, 1975, Deep Sea Drilling Proj. Initial Repts., v. 32, p. 687 , pl. 4 , fig. 1-3.

Remarks: This moderate-sized member of the asperoid group is distinguished from Dictyocha lingii by its thicker bar, unrounded basal ring, and unnoded surface. It is distinguished from Dictyocha varia by its distinctly longer bar, less equant portals, and less rounded basal ring. Discriminating parameters for various forms within the asperoid group are not yet well established.

\section{Dictyocha spinosa (Deflandre)}

(Plate 1, Figures 6-8)

Corbisema spinosa Deflandre, 1950, Microscopie, v. 2, p. 193 , fig. 178-182.

Dictyocha spinosa (Deflandre) Glezer, 1966, Akad. Nauk SSSR, V.A. Komarova Bot. Inst., v. 7, p. 238, pl. 10, figs. 6-8.

Dictyocha hexacantha s. ampl., Bukry and Foster, 1974, U.S. Geol. Surv. J. Research, v. 2, p. 304, fig. lj.

Remarks: Only three of the six spines are in the plane of the basal ring.

\section{Dictyocha sp. (asperoid) \\ (Plate I, Figure 10)}

Remarks: Most of the specimens of Dictyocha at Site 356 are asperoid, having apical bars aligned nearly perpendicular to the long axis of the base. These are generally small, have distinct basal pikes, and typically, canted apical bars. Variants having similar basal-ring style, but medusoid, fibuloid, or deflandroid apical arrays are less abundant and are tabulated together as Dictyocha sp. (variants).

\section{Genus DISTEPHANUS Stöhr, 1880}

Distephanus crux (Ehrenberg) s. ampl. (Plate I, Figure 9)

Dictyocha crux Ehrenberg, 1840, K. Preuss. Akad. Wiss. Berlin, Abh., Jahrg. 1839, p.207.

Remarks: Eocene specimens at Site 356 have moderate to large apical rings but lack basal pikes.

\section{Distephanus speculum pentagonus Lemmermann}

Distephanus speculum var. pentagonus Lemmermann, 1901, Deutsche Bot. Ges., Ber., v. 19, p. 264, pl. 11, fig. 19.

Remarks: Eocene specimens at Site 356 lack basal pikes.

\section{Distephanus speculum speculum (Ehrenberg)}

Dictyocha speculum Ehrenberg, 1839, K. Preuss. Akad. Wiss. Berlin, Abh., Jahrg. 1838, p. 129.

\section{Genus MESOCENA Ehrenberg, 1843}

\section{Mesocena apiculata (Schulz)}

Mesocena oamaruensis apiculata Schulz, 1928, Bot. Archiv, v. 21 , no. 2 , p. 240 , fig. 11 . 


\section{Mesocena circulus (Ehrenberg)}

Dictyocha (Mesocena) circulus Ehrenberg, 1840, K. Preuss. Akad. Wiss. Berlin, Ber., p. 208.

Mesocena circulus (Ehrenberg) Ehrenberg, 1854, Mikrogeologie, p. 19 , fig. 44 .

\section{Mesocena diodon Ehrenberg}

Mesocena diodon Ehrenberg, 1844, K. Preuss. Akad. Wiss. Berlin, Ber., Jahrg. 1844, p. 71, 84.

Mesocena diodon (Ehrenberg) Ehrenberg, 1854, Mikrogeologie, pl. 33 (XV), fig. 18.

\section{Mesocena elliptica (Ehrenberg)}

Dictyocha (Mesocena) elliptica Ehrenberg, 1844, K. Preuss. Akad. Wiss. Berlin, Ber., Jahrg. 1844, p. 71, 84.

Mesocena elliptica (Ehrenberg) Ehrenberg, 1854, Mikrogeologie, pl. 20 (I), fig. $44 a$, b.

Mesocena quadrangula Ehrenberg ex Haeckel, 1887, Challenger Rept., v. 18, p. 1556.

\section{Mesocena oamaruenşis Schulz}

Mesocena oamaruensis Schulz, 1928, Bot. Archiv, v. 21, p. 240, fig. $10 \mathrm{a}, \mathrm{b}$.

\section{Mesocena occidentalis Hanna ex Bukry}

Mesocena oamaruensis var. quadrangula Schulz, 1928 (in part), Bot. Archiv, v. 21, p. 240, fig. 12.

Mesocena occidentalis Hanna, 1931, Mining California, p. 200, pl. E, fig. 1.

Mesocena occidentalis Hanna, Perch-Nielsen, 1975, Deep Sea Drilling Proj. Initial Repts., v. 29 , p. 688 , pl. 10, fig. $15,16$.

Mesocena oamaruensis quadrangula Schulz, Bukry, 1975, ibid., p. 857 , pl. 6 , fig. 4 .

Description: Mesocena occidentalis is a quadrangular ring having a moderate to long spine at each corner. The format is typically square, and ring and spines lie in the same plane. Spines are nonseptate, and surfaces of spines and the straight-sided ring appear smooth in light microscopy.

Remarks: Following Perch-Nielsen (1975), the individual illustrated as fig. 13 of Schulz (1928) is herein designated the lectotype for Mesocena oamaruensis quadrangula Schulz. The companion fig. 14, showing a long-spined form, was referred to Mesocena occidentalis Hanna by Perch-Nielsen. Because there was no diagnosis published with the original illustration for $M$. occidentalis, it has been described herein to validate it and to satisfy ICBN Article 32 .

Mesocena occidentalis Hanna ex Bukry is distinguished from Mesocena venusta by having spines at the corners, from $M$. oamaruensis quadrangula by lacking any septae, and from $M$. elliptica by being more straight-sided and regular in form, having longer spines, and being generally less noded.

Figure 1 of Plate E (Holotype no. 3278 C.A.S.) in Hanna (1931) is herein designated the type specimen for Mesocena occidentalis.

\section{Mesocena tsumurai nom. nov.}

Mesocena oamaruensis var. quadrangula Schulz, 1928 (in part), Bot. Archiv, v. 21 , p. 240 , fig. 13.

non Mesocena quadrangula Ehrenberg ex Haeckel, 1887, Challenger Rept., v. 18, p. 1556.

Septamesocena cf. S. quadrangula (Schulz) Perch-Nielsen, 1975, Deep Sea Drilling Proj. Initial Repts., v. 29, p. 690 , pl. 10, fig. 17,18 .

Remarks: Because of Mesocena quadrangula Ehrenberg ex Haeckel, the newly designated lectotype for Mesocena oamaruensis quadrangula Schulz cannot be elevated to species rank under that name in genus Mesocena. The name Mesocena tsumurai is proposed as a new substitute name for Schulz's taxon at the species level. A substitute name would be superfluous if this taxon were classified in Septamesocena (see Perch-Nielsen, 1975). However, it is not believed at this time that the presence or absence of septae represents a consistent basis for distinction at the genus level.

\section{Mesocena venusta $\mathrm{n}$. sp.}

(Plate 1, Figures 11-13)

Description: Mesocena venusta is a rhomboid ring having rounded, spineless corners. The ring is nonseptate, and the surface appears smooth in light microscopy. The ratio of major to minor axis length ranges from 1.3 to 1.8 .

Remarks: Mesocena venusta is distinguished from $M$. elliptica and $M$. occidentalis by the absence of spines, and from $M$. tsumurai by the lack of spines and septae, and by being more elongate in form.

Occurrence: Mesocena venusta is a rare but distinctive form in the middle Eocene of Core 7 at DSDP Site 356 in the South Atlantic.

Size: Maximum diameter $100 \mu \mathrm{m}$; holotype $80 \mu \mathrm{m}$.

Holotype: USNM 237371 (Plate 1, Figure 11).

Isotypes: USNM 237372 and 237373.

Type locality: South Atlantic Ocean, Sample 356-7-3, 130-131 cm $(137 \mathrm{~m})$.

\section{Genus NAVICULOPSIS Frenguelli, 1940}

Naviculopsis biapiculata (Lemmermann) s. ampl. (Plate 2, Figure 2)

?Dictyocha navicula biapiculata Lemmermann, 1901, Deutsche Bot. Ges., Ber., v. 19 , p. 258 , pl. 10, fig. 14,15 .

Naviculopsis biapiculata (Lemmermann), Bukry, 1975, Deep Sea Drilling Proj. Initial Repts., v. 29, p. 856, pl. 6, fig. 5-8.

Remarks: Eocene specimens at Site 356 have a less rounded ring and a less arched bar than do the more abundant specimens of the upper Oligocene. Further study should differentiate these (see $N$. eobiapiculata Bukry, in press).

To fix the name to barred forms only in the modern usage of genus Naviculopsis, Lemmermann's (1901) pl. 10, fig. 15 specimen, is herein designated the lectotype for Naviculopsis biapiculata.

\section{Naviculopsis constricta (Schulz)}

(Plate 1, Figure 14)

Dictyocha navicula biapiculata constricta Schulz, 1928, Bot. Archiv, v. 21 , p. 246 , fig. 21 .

Naviculopsis constricta (Schulz), Ling, 1972, Am. Paleontol. Bull., v. 62 , p. 183 , pl. 30 , fig. $5-8$.

\section{Naviculopsis danica Perch-Nielsen} (Plate 2, Figure 1)

Naviculopsis danica Perch-Nielsen, 1976, Geol. Soc. Denmark Bull., v. 25 , p. 35 , fig. $5,6,21$.

Naviculopsis danica Perch-Nielsen, Bukry, 1976, Deep Sea Drilling Proj. Initial Repts., v. 35, p. 897 , pl. 9, fig. 3.

\section{Naviculopsis foliacea Deflandre}

Naviculopsis foliacea Deflandre, 1950, Microscopie, v. 2, p. 204, fig. $235-240$.

Naviculopsis foliacea Deflandre, Ling, 1972, Bull. Am. Paleontol., v. 62 , p. 184 , pl. 30 , fig. 9-11.

\section{Naviculopsis quadrata (Ehrenberg)}

Dictyocha quadrata Ehrenberg, 1844, K. Preuss. Akad. Wiss. Berlin, Ber., p. 258, 267.

Naviculopsis quadrata (Ehrenberg), Bukry, 1975, Deep Sea Drilling Proj. Initial Repts., v. 29, p. 856.

\section{Genus MACRORA Hanna, 1932}

\section{(Synonym: Pseudorocella Deflandre, 1938)}

Remarks: Although originally described as a diatom, Macrora could be considered among genera incertae sedis because of its unusual form. Due to its small size, it has generally been described with silicoflagellates as Pseudorocella.

\section{Macrora barbadensis (Deflandre) n. comb.}

$$
\text { (Plate 2, Figures 3-8) }
$$

Pseudorocella barbadensis Deflandre, 1938 (in part), Soc. Franç. Microsc., Bull., v. 7, p. 91, fide Loeblich et al., 1968, Geol. Soc. Am. Mem. 109, p. 139, pl. 33, fig. 4-13, 15-19 (not 14).

Pseudorocella barbadensis Deflandre, Bukry and Foster, 1974, U.S. Geol. Surv. J. Res., v. 2, p. 307, fig. 2 f.

Remarks: These flat, approximately circular and entire-margined fossils are abundant in certain middle Eocene samples from Atlantic DSDP Sites 6, 29, and 356. 


\section{Macrora stella (Azpeitia)}

Pyxidicula(??) stella Azpeitia, 1911, Assoc. Esp. Prog. Cien. Cong. de Zargoza, v. 4, pt. 2, sec. 3, p. $150,152,213$, pl. 1, fig. 1 .

Macrora stella (Azpeitia) Hanna, 1932, California Acad. Sci. Proc. v. 20 , p. 196 , pl. 12 , fig. 7 .

Pseudorocella corona Deflandre, 1947, Bull. Soc. Bot. France, v. 93, p. 337 , fig. 4 .

Pseudorocella corona Deflandre, Stradner, 1961, Erdöl Kohle, v. 14 p. 92, fig. 105, 106.

Pseudorocella corona Deflandre, Bukry, 1975, Deep Sea Drilling Proj. Initial Repts., v. 29 , p. 871 , pl. 7, figs. 8, 9.

Remarks: These forms have raised centers and indented margins. Though usually circular, some specimens are elliptical and have fewer pores (see Stradner, 1961, fig. 106). The early Miocene specimens from Site 338 in the Norwegian-Greenland Sea have fewer pores than the circular multipored variety from Site 278 in the Southern Ocean. Macrora stella was not recognized among the sparse early Miocene silicoflagellates at Site 358

\section{Macrora najae n. sp.}

(Plate 2, Figures 9-12)

Pseudorocella barbadensis Deflandre, 1938 (in part), Soc. Franc. Microsc., Bull., v. 7, p. 91, fide Loeblich et al., 1968, Geol. Soc. Am. Mem. 109, p.139, pl.33, fig. 14

Description: Macrora najae is an elongate, planar, irregular framework of rounded polygonal pores. Peripheral pores are larger than the sinuous, single or double line of interior pores by a factor of about two to four. The margin is lobed about the larger, peripheral pores. Total pore counts range from 10 to 20 (mean 13).

Remarks: Macrora najae is distinguished from $M$. barbadensis by its lobed periphery, elongate shape, and bimodal pore groups. It is distinguished from $M$. stella, which has an indented margin and bimodal pores, by its elongate and more planar form.

Occurrence: Macrora najae is presently known only from the Eocene of the Atlantic region at Barbados, Site 29, and Site 356

Size: Maximum length $30 \mu \mathrm{m}$.

Holotype: USNM 237374 (Plate 2, Figure 11).

Isotypes: USNM 237375 to 237377.

Type locality: South Atlantic Ocean, Sample 356-6-6, 130-131 cm $(123 \mathrm{~m})$.

\section{ACKNOWLEDGMENT}

I thank George W. Moore and John A. Barron, U.S. Geological Survey, and Katharina Perch-Nielsen, Geologisches Institut ETH, Zurich, Switzerland, for their helpful comments and suggestions on various aspects of this study.

\section{ADDENDUM}

Some silicoflagellate figures on page 547 of DSDP Volume 30 are misnumbered. The illustration shown as 10 should read 11 ; change 11 to 13,12 to 14,13 to 10 , and 14 to 12 .

\section{REFERENCES}

Bramlette, M.N. and Wilcoxon, J.A., 1967. Middle Tertiary calcareous nannoplankton of the Cipero Section, Trinidad, W.I.: Tulane Studies Geol., v. 5, p. 93-131.

Bukry, D., 1973a. Low-latitude coccolith biostratigraphic zonation. In Edgar, N.T., Saunders, J.B., et al., Initial Reports of the Deep Sea Drilling Project., Volume 15, Washington (U.S. Government Printing Office), p. 685703.

1973b. Phytoplankton stratigraphy, central Pacific Ocean, Deep Sea Drilling Project Leg 17. In Winterer, E.L., Ewing, J.I., et al., Initial Reports of the Deep Sea
Drilling Project, Volume 17: Washington (U.S. Government Printing Office), p.871-889.

1975. Silicoflagellate and coccolith stratigraphy, Deep Sea Drilling Project Leg 29. In Kennett, J.P., Houtz, R.E., et al., Initial Reports of the Deep Sea Drilling Project, Volume 29: Washington (U.S. Government Printing Office) p. $845-872$.

1976. Cenozoic silicoflagellate and coccolith stratigraphy, South Atlantic Ocean, Deep Sea Drilling Project Leg 36. In Hollister, C.D., Craddock, C., Initial Reports of the Deep Sea Drilling Project, Volume 35: Washington (U.S. Government Printing Office), p. 885918.

in press. Cenozoic silicoflagellate and coccolith stratigraphy, northwestern Atlantic Ocean, Deep Sea Drilling Project Leg 43. In Tucholke, B., Vogt, P., et al., Initial Reports of the Deep Sea Drilling Project, Volume 43: Washington (U.S. Government Printing Office).

Bukry, D. and Foster, J.H., 1974. Silicoflagellate zonation of Upper Cretaceous to lower Miocene deep-sea sediment: U.S. Geol. Surv. J. Res,, v. 2, p. 303-310.

Gartner, S., Jr., 1971. Calcareous nannofossils from the JOIDES Blake Plateau cores and revision of Paleogene nannofossil zonation: Tulane Studies Geol. Paleontol., v. 8 , p. $101-121$.

Glezer, Z.I., 1964. Novye kremnevye zhgutikovye vodorosli Paleogena SSSR [New silicoflagellates from the Paleogene of the USSR]: Akad. Nauk SSSR, Novosti sistematiki nizshikh rasteniy, otdel. ottisk, p. 46-58.

1966, Silicoflagellatophyceae. In Gollerbakh, M.M. (Ed.), Cryptogamic plants of the U.S.S.R.: Akad. Nauk SSSR, V.A. Komarova Bot. Inst. (Translated from Russian by Israel Program for Scientific Translations Ltd., Jerusalem, 1970), v. 7, p. 1-363.

Hanna, G.D., 1931. Diatoms and silicoflagellates of the Kreyenhagen shale: California Div. Mines State Mineral. Rept., v. 27, p. 187-201.

Lemmermann, E., 1901, Silicoflagellatae: Deutsche. Bot. Gesell. Ber., v. 19, p. 247-271.

Ling, H.Y., 1972, Upper Cretaceous and Cenozoic silicoflagellates and ebridians: Am. Paleontol. Bull., v. 62, p. $135-229$.

Martini, E., 1974. Silicoflagellate zones in the Eocene and early Oligocene: Senckenberg. Lethaea, v. 54, p. 527-532.

Perch-Nielsen, K., 1975. Late Cretaceous to Pleistocene silicoflagellates from the southern southwest Pacific, DSDP Leg 29. In Kennett, J.P., Houtz, R.E., et al., Initia Reports of the Deep Sea Drilling Project, Volume 29: Washington (U.S. Government Printing Office), p. 677. 721

Schulz, P., 1928. Beiträge zur Kenntnis fossiler und rezenter Silicoflagellaten: Bot. Archiv, v. 21, p. 225-292.

Stradner, H., 1961. Uber fossile Silicoflagelliden und die Möglichkeit ihrer Verwendung in der Erdölstratigraphie: Erdöl Kohle, v. 14, p. 87-92.

Thierstein, H.R., 1971. Tentative Lower Cretaceous calcareous nannoplankton zonation: Eclog. Geol. Helv., v. 64 , p. $459-487$. 
PLATE 1

Silicoflagellates from DSDP Leg 39

All figures at magnification $800 \times$; scale bar equals $10 \mu \mathrm{m}$.

Figure $1 \quad$ Corbisema bimucronata Deflandre.

Sample 356-6-6, 130-131 cm (123 m).

Figure $2 \quad$ Corbisema hastata globulata Bukry.

Sample 356-8-2, 130-131 cm (164 m).

Figure 3 Corbisema inermis inermis (Lemmermann).

Sample 356-7-1, 130-131 cm (134 m).

Figures 4, 5 Corbisema lamellifera (Glezer).

Sample 356-6-6, 130-131 cm (123 m).

Figure 6-8 Dictyocha spinosa (Deflandre).

6. Sample 356-6-6, 130-131 cm (123 m).

7. Sample $356-8-1,130-131 \mathrm{~cm}(162 \mathrm{~m})$, apical focus.

8. Sample 356-8-1,130-131 cm (162), basal focus.

Figure 9 Distephanus crux (Ehrenberg) s. ampl.

Sample 356-7-1, 130-131 cm (134 m).

Figure $10 \quad$ Dictyocha sp. (asperoid).

Sample 356-7-1, 130-131 cm (134 cm).

Figures 11-13 Mesocena venusta n. sp.

11. Holotype, USNM 237371, Sample 356-7-3, $130-131 \mathrm{~cm}(137 \mathrm{~m})$.

12. USNM 237372, Sample 356-7-5, 130-131 cm (140 m), fragment.

13. USNM 237373, Sample 356-7-1, 130-131 cm $(134 \mathrm{~m})$, obscured specimen.

Figure $14 \quad$ Naviculopsis constricta (Schulz).

Sample 356-6-6, 130-131 cm (123 m). 


\section{PLATE 1}
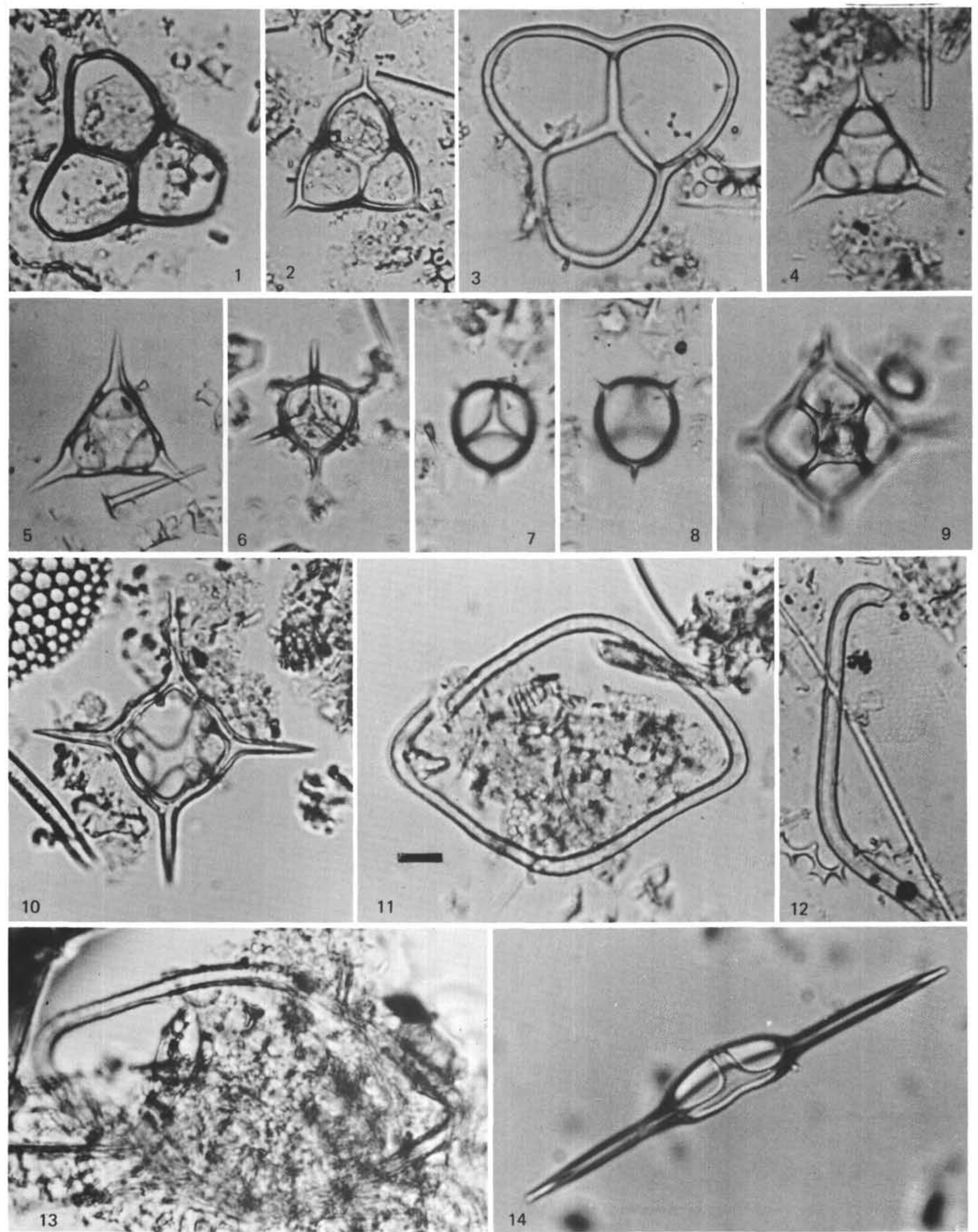
PLATE 2

Silicoflagellates and Diatoms from DSDP Leg 39

Figures 1-14, 17 at magnification $800 \times$; scale bar equals $10 \mu \mathrm{m}$. Figures 15, 16 at magnification 500X; scale bar equals $10 \mu \mathrm{m}$.

Figure $1 \quad$ Naviculopsis danica Perch-Nielsen. Sample 356-7-5, 130-131 cm (140 m).

Figure 2 Naviculopsis biapiculata (Lemmermann) s. ampl. Sample 356-8-2, 130-131 cm (164 m).

Figures 3-8 Macrora barbadiensis (Deflandre). All specimens from Sample 356-6-6, 130-131 cm (123 m).

Figures 9-12 Macrora najae n. sp.

All specimens from Sample 356-6-6, 130-131 cm (123 m).

9. USNM 237375.

10. USNM 237376.

11. Holotype, USNM 237374.

12. USNM 237377.

Figure 13 Asterolampra decora Greville, var. nov. of Castracane (1886).

Sample 356-9-1, 130-131 cm (190 m).

Figure $14 \quad$ Brightwellia sp. cf. B. pulchra Grunow. Sample 356-9-2, 130-131 cm (192 m).

Figure $15 \quad$ Brightwellia sp.

Sample 356-9-1, 130-131 cm (190 m).

Figure 16 Actinocyclus sp. cf. A. bisenarius Ehrenberg.

Sample 356-9-1, 130-131 cm (190 m).

Figure 17 Craspedodiscus oblongus (Greville).

Sample 356-6-6, 130-131 cm (123 m). 
PLATE 2

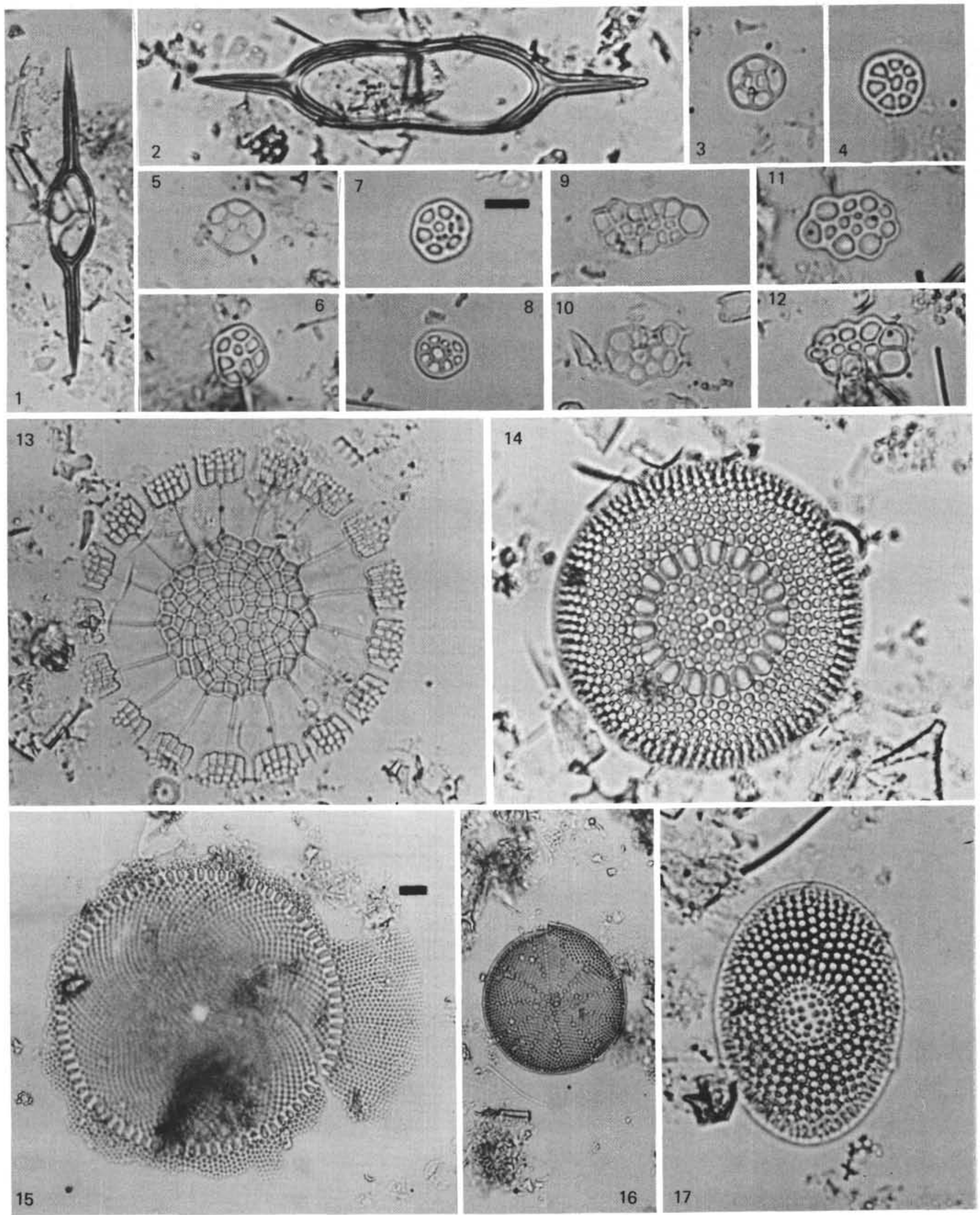




\section{PLATE 3}

Diatoms from DSDP Legs 21 and 39

Figure 1 at magnification $500 \times$; scale bar equals $10 \mu \mathrm{m}$.

Figure 2 at magnification $1100 \times$; scale bar equals $10 \mu \mathrm{m}$.

Figures 3-7 magnification $800 \times$; scale bar equals $10 \mu \mathrm{m}$.

Figures 1, 2 Hemiaulus sp.

Sample 356-6-6, 130-131 cm (123 m). Structures shown here suggest that the Eocene Thalassiothrix? sp. in DSDP Volume 17 (Bukry, 1973b) may be a fragment of a Hemiaulus sp.

Figures 3-5 Trinacria? sp.

Sample 356-9-1, 130-131 cm $(190 \mathrm{~m})$.

3 , 4. Surface and profile focuses of same specimen.

5. General focus.

Figures 6,7 Diatom sp. 1. Compare Rylandsia biradiata Greville-Schmidt Atlas, pl. 137/23-25.

6. Sample $356-9-1,130-131 \mathrm{~cm}(190 \mathrm{~m})$.

7. Sample 208-27-5, 103-104 cm (490 m). 


\section{PLATE 3}

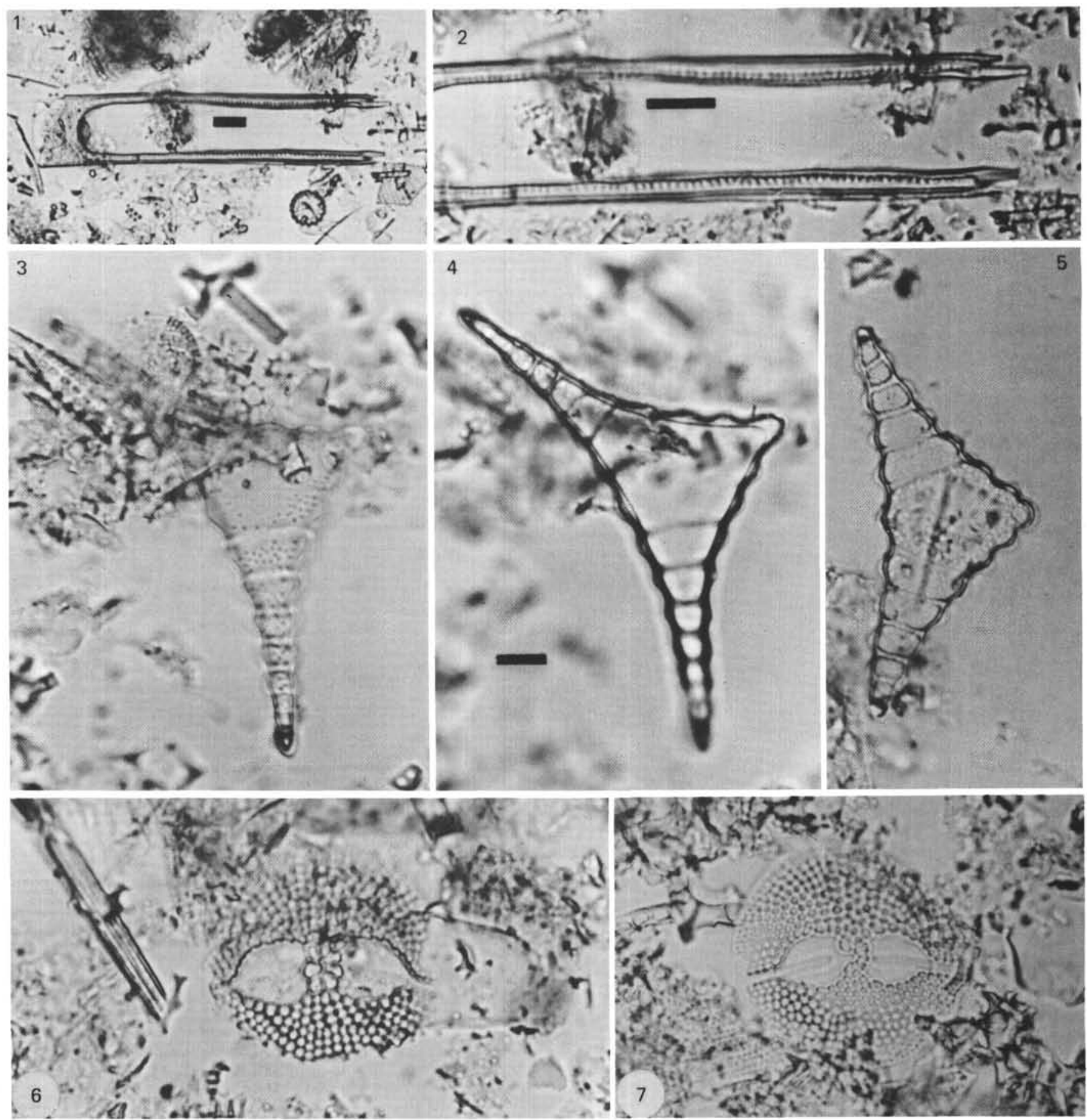

